\title{
THE WAYS OF INCREASING COMPETITION IN SOCIAL SERVICES SECTOR
}

\author{
GULYOR KOSIMOVA \\ Tashkent institute of Finance, Tashkent, Uzbekistan
}

\section{ABSTRACT}

The paper studies methods of calculation of competiveness of social service providers in Tashkent city (Uzbekistan). Specific factors forming economic-mathematical factors of competiveness of organizations (providers) of education, healthcare and cultural services are presented. As research shows all social services (public and commercial) of human capital development in Uzbekistan regulated by the same legislation for all citizens (in some cases, according legislation, these services are "free" for particular consumers). The main mechanism of increasing competiveness of organization is integration to public-private partnerships the research proved. The author suggests this partnership also is effective mechanism to improve competiveness.

\section{JEL CLASSIFICATION \& KEYWORDS}

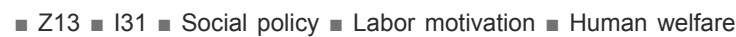
- Competition = Public-private partnerships - Consumers

\section{INTRODUCTION}

Social policy as part of government policy considers of increasing welfare, human capital development, supplying social services and improving social infrastructure.

Social policy carries out according to the constitutional rights of the citizens. Legislation, norms, standards, programs, grants, budgetary financing and etc. are the mean instruments of social policy implementation. Also providing social guarantees, increasing labor motivation are the basis for success of social reforms.

The analysis of competition in social services sector in Uzbekistan

Today's existing social services system in Uzbekistan are reliable and proving it's practical social support to all population. Social reforms oriented towards building human centered society in Uzbekistan. The reforms based on factors such as success of problem solving in social welfare area, creating reliable social guarantees and increasing labor motivation. The measures of social development and regulation defines it's main tasks, which are the following:

- Economic activity stimulation,

- human capital development,

- providing social society stability.

As noted by Theodor Shultz [4], within process of seeking new factors of economic growth factory worker can be transformed to leaders who can analyze situation and motivated to find the answers of production problems.

Human capital is defined as:

- Reserves of health, knowledge, news, talent and motivation,

- knowledge, news, talent,

- investments to knowledge improvement, new things and human talent.

Social stability in society will be provided by creating different social services which in turn guaranteed by Constitution of the country. Organizing social institutions and mechanisms supported by the state to make their work more efficient. Providing stable economic growth, development of national production, creating positive business climate and improving the life level of population are the main goals of socio-economic reforms in Uzbekistan. Of course, the system of social services is main instrument of providing these tasks. Spending on social-cultural activities from state budget is explained as government's social function and provides citizens social guarantees.

Table 1 presents the increasing budget spending on social sector and social welfare during the studied period in Uzbekistan.

\begin{tabular}{|c|c|c|c|c|c|c|}
\hline \multirow[b]{2}{*}{ № } & & \multicolumn{5}{|c|}{ Years } \\
\hline & & 2007 & 2008 & 2009 & 2010 & 2011 \\
\hline 1 & $\begin{array}{l}\text { State budget expenditure, } \\
\text { summary (without other } \\
\text { state fund spending) }\end{array}$ & 100 & 100 & 100 & 100 & 100 \\
\hline 2 & $\begin{array}{l}\text { Social-cultural sector and } \\
\text { social welfare expenditure }\end{array}$ & 54,1 & 53,6 & 56,5 & \begin{tabular}{|l|}
59,1 \\
\end{tabular} & 59,5 \\
\hline 5 & $\begin{array}{l}\text { Economic sector } \\
\text { expenditure }\end{array}$ & 12,1 & 12,5 & 11,9 & 11,5 & 11,4 \\
\hline 6 & $\begin{array}{l}\text { Financing centralized } \\
\text { investments }\end{array}$ & 8,6 & 7,9 & 7,5 & 4 & 5,6 \\
\hline 7 & $\begin{array}{l}\text { Government, legislation } \\
\text { sector expenditure }\end{array}$ & 2,2 & 2,5 & 2,4 & 1,1 & 2,7 \\
\hline 8 & \begin{tabular}{|l|} 
Financing self- \\
government organizations
\end{tabular} & 0,7 & 0,8 & 0,7 & 0,9 & 0,8 \\
\hline 9 & $\begin{array}{l}\text { The reserve fund of } \\
\text { government of Uzbekistan }\end{array}$ & 0,4 & 0,4 & 0,3 & 0,4 & 0,3 \\
\hline & Other expenditure & 21,9 & 22,3 & 20,7 & 23 & 19,7 \\
\hline
\end{tabular}

The governments program towards easing the affects of global crisis to the uzbek economy for the 2009-2012 years was implimented succsessfuly.

"Creating effective social infrastructure and attraction of internal resources to technologic modernization of important sectors of uzbek economy such as real sectors and transport system within anti-crisis state program taken as main priority"1. Social justice and social defense system principals are the basis of providing social policy in social oriented market economy. Social equality, providing social guarantees and increasing of human welfare are the tasks fulfilled within society development. Government should give priority to factors of social development, increasing of population welfare, and of course, should create legislation basis of reforms in social service sectors.

State social services will differentiate from other services with some characteristics. For example, social services are the wealth of the society, they are provided to serve to the whole society and anyone in the country can use these services. We study social services first as the activity of

1 I.Karimov. Asosiy vazifamiz -Vatanimiz taraqqiyoti va halkimiz faravonligini yanada yuksaltirishdir. Tashkent. Uzbekistan. 2010. $-43 p$. 
THE WAYS OF INCREASING COMPETITION IN SOCIAL SERVICES SECTOR

\begin{tabular}{|l|l|}
\hline Table 2: The classification of social services \\
\hline The signs of social services & The classification of social services \\
\hline \multicolumn{2}{|c|}{ As the process of social services } \\
\hline According to social sector branches & $\begin{array}{l}\text { Social services within formation and development of human capital (service sector), social } \\
\text { support services (non- production sector) }\end{array}$ \\
\hline According to service sector branches & Education, healthcare, culture, sport and etc. \\
\hline According to ownership & State social services and municipal social services, private social services \\
\hline According to financial sources & $\begin{array}{l}\text { State and municipal budget resources, other state funds, social services financed by } \\
\text { sponsors }\end{array}$ \\
\hline According to capital expenditure level & Needs high level of capital expenditure, does not need high capital expenditure \\
\hline According to material expenditure level & $\begin{array}{l}\text { Social services which demand many material expenditure, social services which does not } \\
\text { demand many material expenditure, }\end{array}$ \\
\hline According to personal specialists & Provided by highly qualified specialists, provided by skilled specialists \\
\hline \multicolumn{2}{|c|}{ Social service as economic wealth } \\
\hline According to payment & Free and commercial social services \\
\hline According to consumption characteristics & Collective social services, \\
\hline \multicolumn{2}{|l|}{} \\
\hline According to standardization & individual social services \\
\hline According to human capital development & Standard social services, non-standard social services \\
\hline According to consumption status & Highly tailored (exclusive) social services, for public social services \\
\hline Source: Author &
\end{tabular}

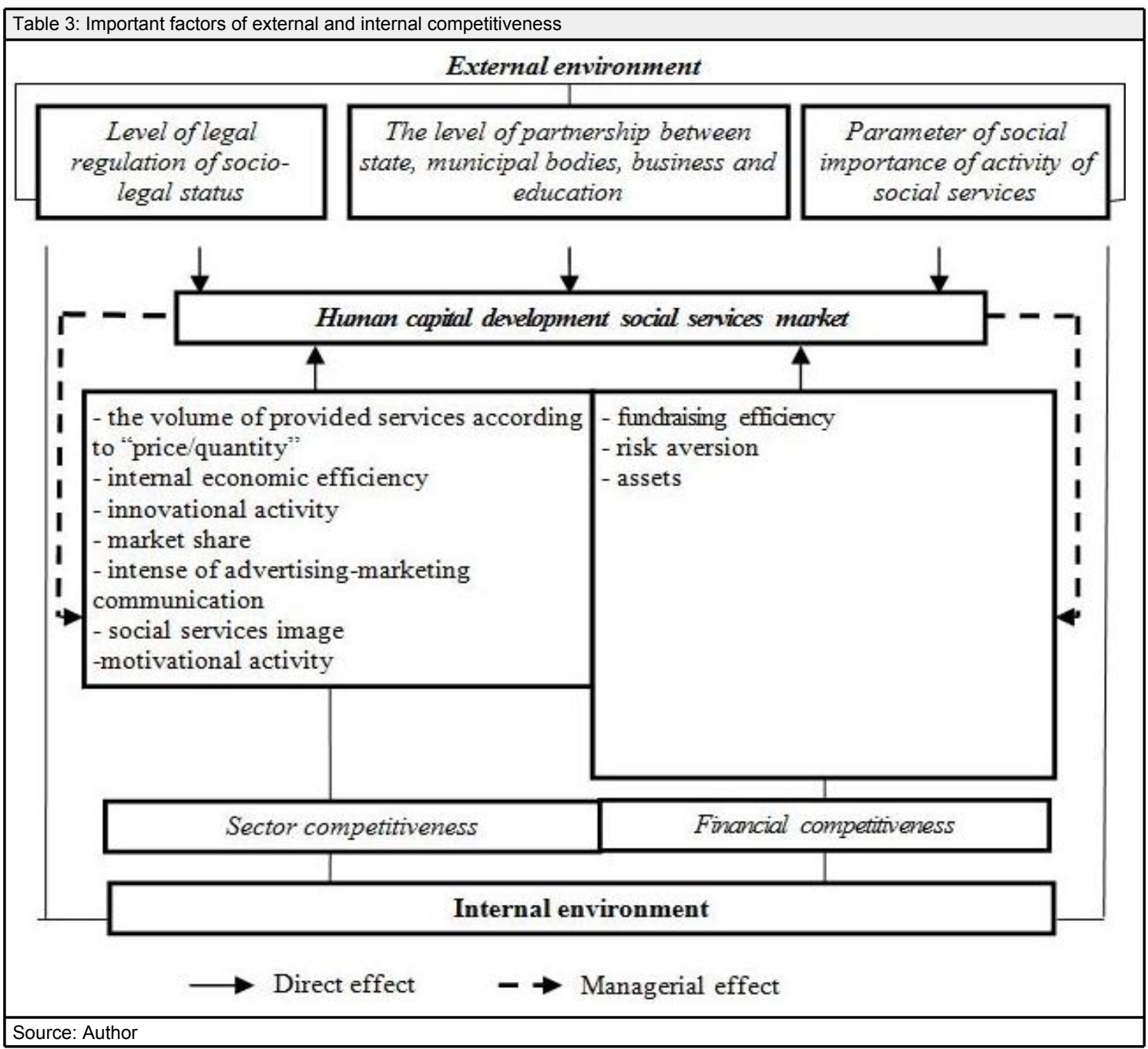


formation and development of human capital interconnected with the movement of other members of society, second, the type of national wealth and as it's part(taking into account the characteristics of social services). As a result of our research we classified social services as in Table 2.

"Our main short-term task - actively continuing started reforms - social sector development to increase consumption demand, giving special attention to increase wages, development of services and infrastructure sectors, fulfilling transport and communication projects"2. Social services sector needed to employ all opportunities of modernization and innovation and should be developed according to the contemporary requirements. Market relations should be more implied in social services sectors and competition environment should be created among social service providers.

The model

Table 3 provides more important factors of external and internal competitiveness in social services market of human capital development and their share.

Internal and external factors of competition of social services build in compound system (according to their importance) are the basis for evaluation of economic-mathematical model and social services competition management. This method is used to evaluate competiveness of noncommercial social service organizations.

On first stage, all necessary data about competitors should be gathered, together with trends in demand and supply in markets of education, healthcare services and services in cultural sector.

On the second stage the important external and internal factors of organizational competiveness should be defined to provide success in markets.

On the third stage, the character and level of effects of these factors to competiveness needed to be studied together with social and economic variables resulting these factors.

On the fourth stage integrated variable of competiveness is calculated (given as valuation of target function model) and presented as competiveness of human capital development social services.

We suggest, integrated rating of competition should be calculated by summarizing all points of evaluation of main factors of competition and coefficients of importance given by experts.

There are manageable internal factors of competiveness and external factors (unmanageable) in economicmathematical model of competitiveness evaluation. That's why we need some corrections for unmanageable external factors in this model. The model can be presented as summary of all factors of competiveness social services of human capital development:

$$
\begin{gathered}
K S^{N P O}=\left(\xi_{1} \cdot L I+\xi_{2} \cdot L R+\xi_{3} \cdot L S\right)+\left(\eta_{1} \cdot V(P, Q)+\eta_{2} \cdot E E+\right. \\
\eta_{3} \cdot M P+\eta_{4} \cdot I^{N P O}+\eta_{5} \cdot A s^{N P O}+\eta_{6} \cdot I^{N P O}+\eta_{7} \cdot F^{N P O}+ \\
\left.\eta_{8} \cdot M C^{N P O}+\eta_{9} \cdot R^{N P O}+\eta_{10} \cdot M^{N P O}\right) \rightarrow \max
\end{gathered}
$$

where:

KSNPO - competiveness of human capital development social service organization,

\footnotetext{
2 I.Karimov. Mamlakatimizda demokratik islohotlarni yanada chukurlashtirish va fukorolik jamiyatini rivojlantirish kontsepsiyasi. The speech of the President of the Republic of Uzbekistan I. Karimov at joint meeting of Parliament and Senate of the Republic of Uzbekistan. November 16, 2010.
}

$\mathrm{LI}$ - the level of partnership between government, municipal bodies, business's and social sector,

$L R$ - the level of legal regulation of economic-legal status,

LS - parameter of social importance of activity,

$\xi$ - share coefficient of competiveness factors (external factors),

$\mathrm{V}(\mathrm{P}, \mathrm{Q})$ - the volume of provided services according to "price/quality" measures,

EE - parameter of economic efficiency of social services,

$M P$ - the market share of social services,

ImNPO - image of social services,

AsNPO - budget organization assets,

InNPO - innovation and mobility,

FNPO - fundraising efficiency,

$\mathrm{MC}^{\mathrm{NPO}}$ - the level of advertisement-marketing communication,

RNPO - stability of social services to risks,

MNPO - motivation component in social services activity,

$\eta$ - the share coefficient of social services competiveness (internal factors).

The suggested general model of competiveness of social services organization presents universal character and can be used within any organization in human capital development market.

The following specific factors taken into account to clarify model implementation to different segments of human capital development social services market: sector specifics of budget organization in education, healthcare, cultural markets to build three economic-mathematical model with variables characterizing all target markets - education, healthcare, cultural markets.

\section{Conclusion}

1. The research studies methods of calculation of competiveness of social service providers of human capital development in Tashkent city. Specific factors forming economic-mathematical factors of competiveness of organizations (providers) of education, healthcare and cultural services are presented. One of mechanisms of increasing competiveness of organization is integration to public-private partnerships the research studied. The author suggests this partnership is effective mechanism to improve competiveness.

2. Human capital development social services are characterized with complex of market and non-market dialects, collective and individual starts, possess specific characters resulted by external effects differentiating them from other services.

3. Social services for the development of human capital are specifies as public welfare and welfare for individual use integrated in market relations, which shows it's dual character.

4. Social services for human capital development provision will be evaluated not only within economic measures, but how it is socially effective.

5. The dual character of social services are resulted from (specifying public and private) external effects. The importance of social services market requires state regulation of these services.

6. All social services (public and commercial) of human capital development in Uzbekistan regulated by the one 
legislation for all citizens. In some cases, according legislation, these services are "free" for particular consumers, which in turn will be paid by state budget.

\section{REFERENCES}

1. I.Karimov. The main goal - development of our country and population welfare. Tashkent. Uzbekistan. 2010. - 80 p.

2. The speech of the President of the Republic of Uzbekistan I. Karimov at joint meeting of Parliament and Senate of the Republic of Uzbekistan. November 16, 2010.

3. The decree \#1449 of the President of The Republic of Uzbekistan on «About the main macroeconomic parameters for 2011 of the Republic of Uzbekistan and state budget». December 24. 2009.

4. Schultz T. Investment in Human Capital/ - the Role of Education and of Research. H.Y., 1971. 62.

5. A.Vahabov, G.Kosimova. Public finance management. Textbook.T.:«IQTISOD-MOLIYA», 2008. 287 p.

6. G.Kosimova. Budgetary police for social-cultural sectors development. «MOLIYA». T., 2004. 152 p.

7. G.Kosimova. The main directions of social policy. -T.: «IQTISODMOLIYA», 2008. 112p.

8. S.Kirillova. Quality valuation of budget services in regions: economical-mathematical model. //Problemi sovremennoy ekonomiki.. №4, 2008. - 387p. 